\title{
Significance of the measurement of serum fructosamine in the management of childhood diabetes
}

\author{
Youn Shim Shin, Jiyun Park, Dong Soo Kang, Jeesuk Yu* \\ From 7th APPES Biennial Scientific Meeting \\ Nusa Dua, Bali. 14-17 November 2012
}

\begin{abstract}
Aims
HbA1c can usually be used as the indicator of glucose control and correlated with the development of long-term diabetic complications. But there are limits that it usually reflects the mean glucose levels of 2-3 months and can be variable in the situation of hemoglobinopathy or the conditions of altered RBC lifespan. In contrast, serum fructosamine levels reflect the mean glucose levels of 23 weeks. This study was designed to see the significance of the measurement of serum fructosamine in the management of childhood diabetes and to see the correlation between the HbA1c and fructosamine.
\end{abstract}

\section{Methods}

Clinical data were evaluated for the sixty Korean patients who are on the management of diabetes in the department of Pediatrics, Dankook University Hospital. Fructosamine and HbA1c levels were also reviewed on the basis of clinical information and analyzed using IBM SPSS Statistics version 20.

\section{Results}

HbA1c and fructosamine levels showed strong association $(\mathrm{p}<0.001)$. Fructosamine levels indicated the average glucose concentration over the previous $2-3$ weeks better than $\mathrm{HbA1c}$, so were useful for the evaluation of the therapeutic efficacy of recent change of therapeutic modality as well as for the diagnosis of fulminant diabetes.

\section{Conclusion}

The measurement of fructosamine levels was useful in the management of childhood diabetes especially, if

Department of Pediatrics, Dankook University Hospital, Cheonan, Republic of Korea

(c) 2013 Shin et al; licensee BioMed Central Ltd. This is an Open Access article distributed under the terms of the Creative Commons Attribution License (http://creativecommons.org/licenses/by/2.0), which permits unrestricted use, distribution, and reproduction in any medium, provided the original work is properly cited. there is some discrepancy between the clinical information and HbA1 levels. In addition, it was useful for the short-term evaluation about the recent glucose control after the change of the treatment modality of diabetes.

Published: 3 October 2013

doi:10.1186/1687-9856-2013-S1-P36

Cite this article as: Shin et al: Significance of the measurement of serum fructosamine in the management of childhood diabetes.

International Journal of Pediatric Endocrinology 2013 2013(Suppl 1):P36.
Submit your next manuscript to BioMed Central and take full advantage of:

- Convenient online submission

- Thorough peer review

- No space constraints or color figure charges

- Immediate publication on acceptance

- Inclusion in PubMed, CAS, Scopus and Google Scholar

- Research which is freely available for redistribution

Submit your manuscript at www.biomedcentral.com/submit
() Biomed Central

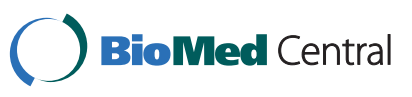

